\title{
SOME CIRCULATION FEATURES DURING SOUTH-WEST MONSOON IN SOUTHERN VIETNAM'S WATERS
}

\author{
Le Dinh Mau*, Nguyen Chi Cong, Nguyen Van Tuan \\ Institute of Oceanography, VAST \\ *E-mail: ledinhmau.vnio@gmail.com
}

Received: 10-8-2016

\begin{abstract}
This paper presents some circulation features during South-West (SW) monsoon in Southern Vietnam's waters. The data were collected from different projects which were carried out by the Institute of Oceanography in recent years. Study results show that during SW monsoon the current mostly flows from the south to the north by wind action, and it is the period of high Mekong river discharge. These conditions are the main causes of Mekong river water spreading to the Central Vietnam upwelling area. Measured data during August and September 2009 indicate that Mekong River water spreads up to about $80 \mathrm{~km}$ to $100 \mathrm{~km}$ offshore, inclining in the northern part of Mekong river mouth region towards the upwelling area. The extent of river water spreading is directly proportional to the Mekong river discharge and SW monsoon intensity. This phenomenon is significant feature for assessment of the ecological-environmental effects on the upwelling area.
\end{abstract}

Keywords: Current, Mekong river, upwelling, ecological-environmental, monsoon.

\section{INTRODUCTION}

Circulation pattern in Southern Vietnam's waters is driven mostly by the East Asian monsoon, tidal regime and extreme events such as typhoon, coastal flood,... The main oceanographic features are the "westward intensification effect" during North-East (NE) monsoon, and upwelling phenomenon during SW monsoon, the dispersion of Mekong river waters to the Eastern Vietnam Sea. These oceanographic processes have effected ecosystem and marine biological resources in the studied area. The circulation system in the Eastern Vietnam Sea has been studied by several researchers; especially, Shaw and Chao (1994) [1] used 3D circulation model to study the surface circulation, Pohlmann (1987) [2] developed a 3D circulation model. Dinh Van Uu (2011) [3] has developed a forecasting model system on hydrodynamic processes.
Herein, the features of strong cold current system flowing from the north to south the during NE monsoon and upwelling phenomenon during SW monsoon in studied area were presented. In South Vietnam waters the remarkable study conducted by Hein et al., (2013) [4] focused on the feature of interannual variability of upwelling off the Southern Vietnam's coast and its relation to nutrient dynamics, that by Hein et al., (2013) [5] focused on the sediment dynamics in the region of Mekong river water influence. The main meteo-hydrological features were studied by Le Dinh Mau et al., (2011) [6]. However, most of above study results were based on numerical model whereas this study result is mainly based on observation data which were carried out by the Institute of Oceanography (IO) in recent years under the international cooperation project between Vietnam and Germany (20032009). The content of this paper focuses on the 
feature of circulation pattern and spreading of Mekong river waters to the upwelling region in Southern Vietnam's waters with the studied area covering the waters from Khanh Hoa to $\mathrm{Ca}$ Mau including Phu Quy and Con Dao islands. Location and feature of studied area are shown in fig. 1 .

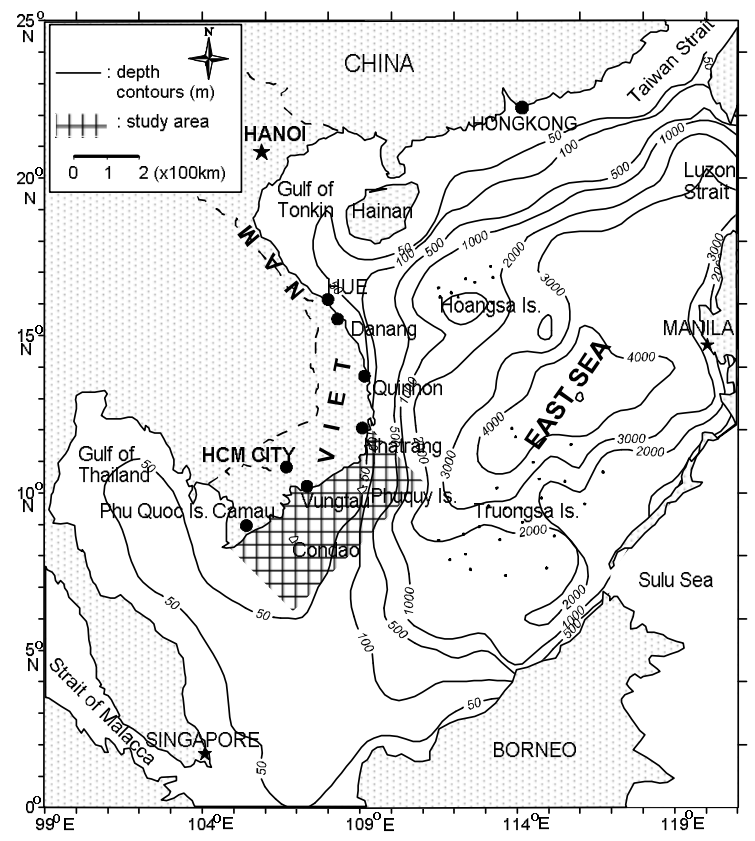

Fig. 1. Bathymetry of the Eastern Vietnam Sea and location of the studied area

\section{MATERIAL AND METHOD}

The main data of this paper were based on recent study results from different projects which were carried out by the Institute of Oceanography, especially "Study on the upwelling phenomenon and related processes" (Vietnamese - German Joint Project: 20032006), "Study on the interaction between Mekong river waters and upwelling region" (Vietnamese - German Joint Project: 20072010) and some related projects. Herein, wind data were collected from Phu Quy station (1987-2007), Mekong river discharge data were collected from Can Tho and My Thuan stations (1997-2007), hourly water level data were collected from Vung Tau station (1987-2006), bottom topography in the studied area was taken from hydrographic map with scale of
$1 / 50,000$ published in 2004 by Vietnamese Navy [6]. Hydrodynamic data were collected from five cruises for low $(4 / 2007,4 / 2010)$ and high (8/2009, 9/2008, 9/2009) Mekong river discharges. Field investigated stations are shown in fig. $2 \mathrm{a}, 2 \mathrm{~b}, 2 \mathrm{c}, 2 \mathrm{~d}$.

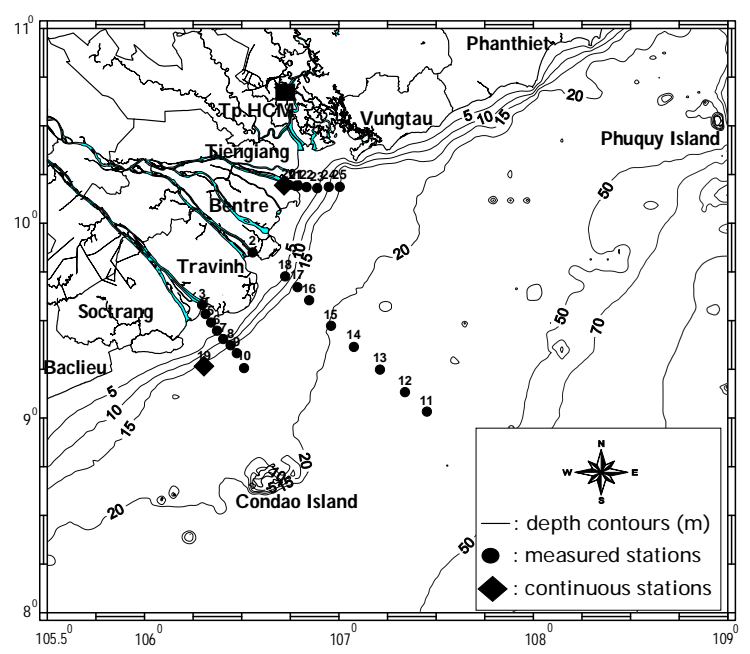

Fig. 2a. Measured stations of cruise 4/2007

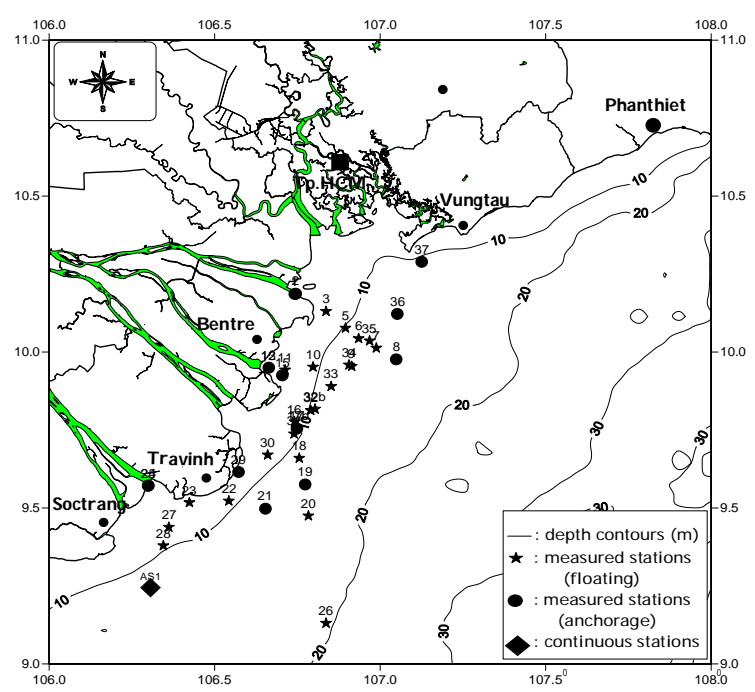

Fig. 2b. Measured stations of cruise 9/2008

The measurement instruments used are Seabird equipment for water temperature and salinity, Alex-compact equipment for current parameters. Continued stations (LT) for 25 hours were carried out at Cung Hau - Co Chien mouth area and at Vung Tau transect. The remaining stations were measured by mooring 
ship. Circulation system in upwelling area were computed by HAMSOM model (HAMburg Shelf Ocean Model) which was developed by Hamburg University (https://csdms.colorado.edu/wiki/Model:HAMS OM) [4]. The reference to estimate the influence of fresh water on the sea was based on the NAGA Expedition Report "The physical oceanography of the Gulf of Thailand" by Robinson in 1974 [7].

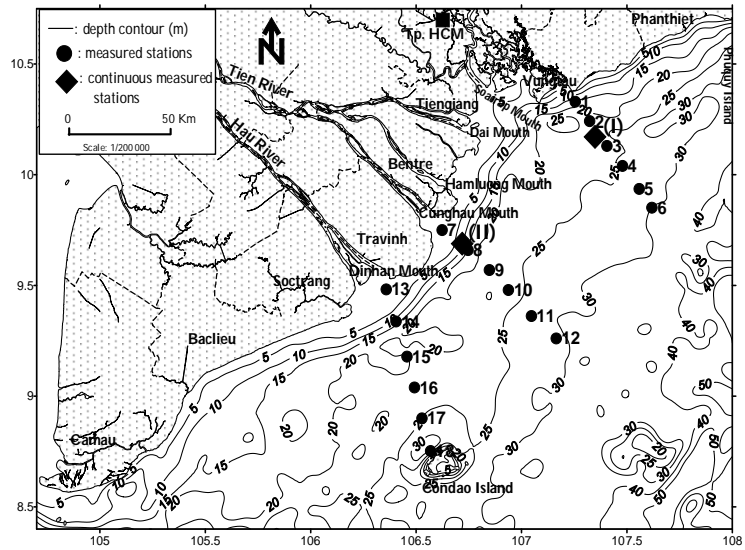

Fig. 2c. Measured stations of cruises 9/2009 and $4 / 2010$

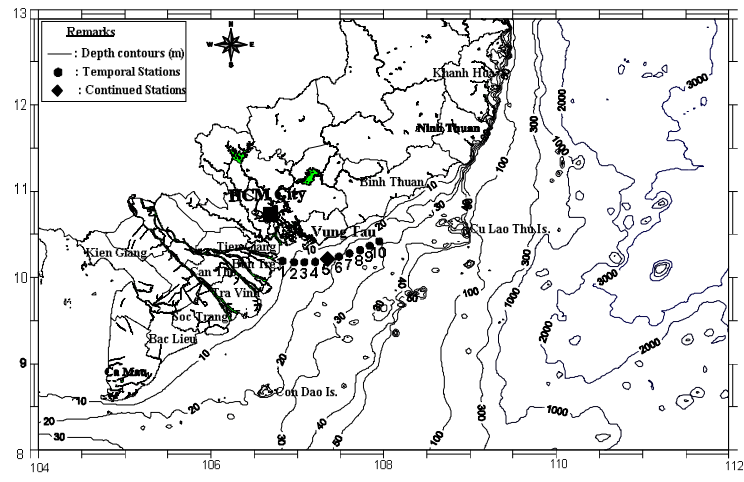

Fig. 2d. Measured stations of cruise 8/2009

\section{STUDY RESULTS}

\section{Features of natural conditions along Southern Vietnam's Coast}

\section{Geo-morphological features}

The northern coast of studied area (Nha Trang to Vung Tau) is lying in NE-SW direction, it means the coastline direction is parallel with two main monsoonal wind directions (NE and SW monsoons). The coast can again be divided into several sections by headlands which form bay with the mouth in $\mathrm{SE}$ direction. The shelf has a relative slope with the depth contour of $200 \mathrm{~m}$ lying at distance of about $100 \mathrm{~km}$ offshore. Almost all the rivers are short, suspended matter concentrations are relatively low.

Southern part (Vung Tau - Ca Mau) with main feature being the coastline is also lying in NE-SW direction. The coast can be divided into several parts by different estuaries. The shelf is relatively less sloping compared with that of the northern part, with the depth contour of $30 \mathrm{~m}$ lying at distance of $\approx 100 \mathrm{~km}$ offshore. Suspended matter concentration from the Mekong river is relatively high.

\section{Meteo-hydrological conditions}

Distribution feature of SW monsoon wind in the studied area is shown in fig. 3.

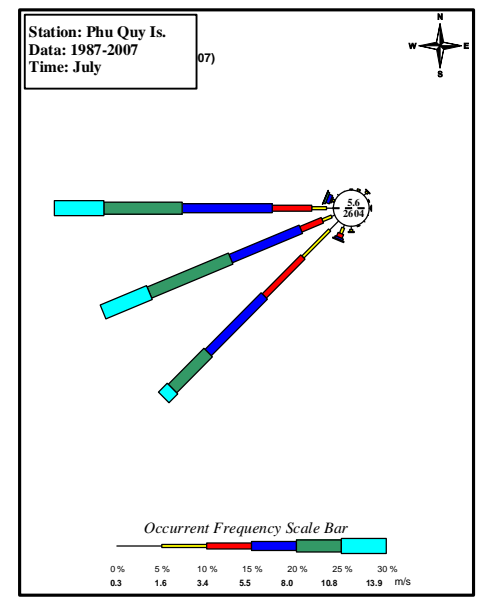

Fig. 3. Wind rose diagram at Phu Quy station in July (1987-2007)

The data in fig. 3 show the distribution of wind velocity and direction at Phu Quy station (offshore region of studied area) which indicate that during SW monsoon the wind direction is in the sector from SW to W.

Typhoons in the studied coast mostly occur from October to December, especially in November. The coast from Binh Thuan to $\mathrm{Ca}$ $\mathrm{Mau}$ is less affected by typhoons. The occurrence of typhoons is delayed from the 
northern part (November) to southern part (December) of the studied area.

The tidal regime along the studied coast is from irregular diurnal tide in the northern part to irregular semi-diurnal tide in the southern part. Mean high tide amplitude is approximately $1 \mathrm{~m}$ along northern coast (Nha Trang - Vung Tau), and about $2 \mathrm{~m}$ along southern coast (Vung Tau - Ca Mau).

\section{Mekong river discharge}

Mekong river in Vietnam is divided into two main branches that are Hau and Tien rivers. River discharge data (from 1998 to
2007) at two branches were collected (My Thuan station on Tien river; Can Tho station on Hau river). Analysis results show that the variations of monthly river discharge at two stations are similar to the maximum value in September and the minimum value in March and April (fig 4a, 4b). In the flood season (July - December) the discharge ranges from $4,000 \mathrm{~m}^{3} / \mathrm{s}$ to $15,800 \mathrm{~m}^{3} / \mathrm{s}$, in the dry season (January - June) the discharge value is less than $4,000 \mathrm{~m}^{3} / \mathrm{s}$ for each station. The minimum value of discharge was $760 \mathrm{~m}^{3} / \mathrm{s}$ in April 2004 at Can Tho station and $800 \mathrm{~m}^{3} / \mathrm{s}$ in March 2005 at My Thuan station.

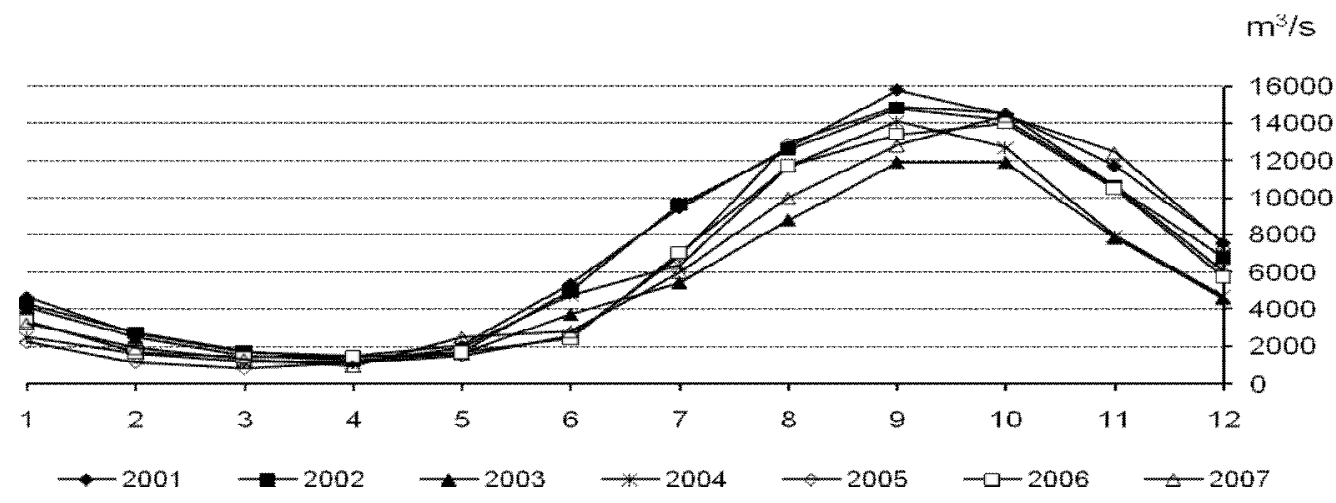

Fig. 4a. Variation of monthly river discharge at My Thuan station from 2001 to 2007 (Vertical axis: River discharge $\left(\mathrm{m}^{3} / \mathrm{s}\right)$; Horizontal axis: Months)

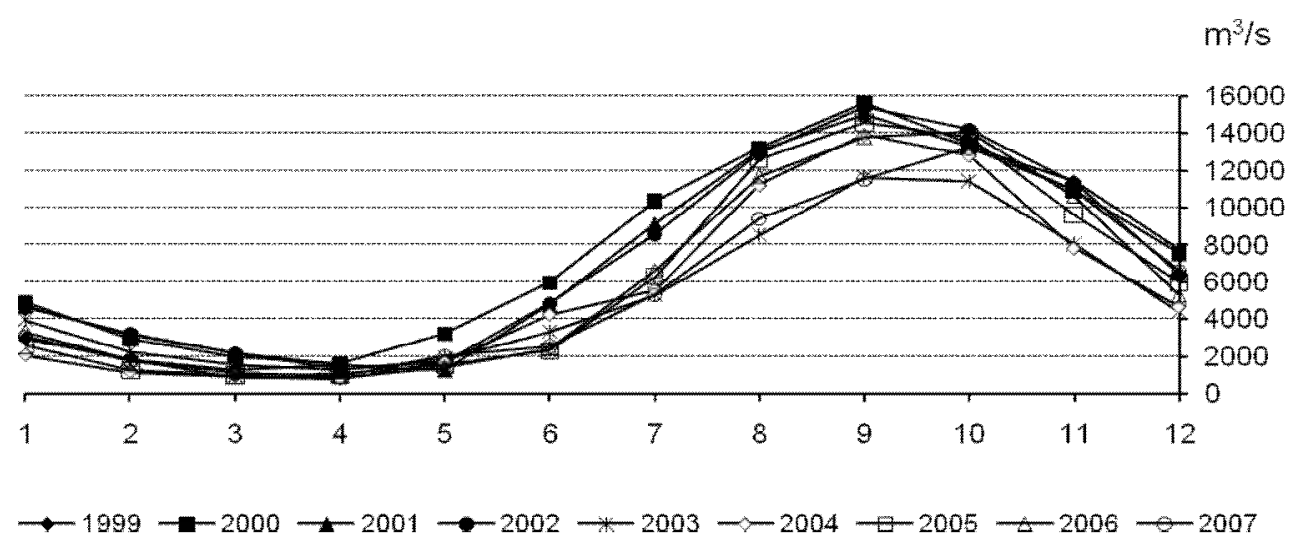

Fig. 4b. Variation of monthly river discharge at Can Tho station from 1999 to 2007 (Vertical axis: River discharge; Horizontal axis: Months)

\section{Circulation features and upwelling phenomenon in Southern Vietnam's waters}

\section{Upwelling phenomenon}

Using HAMSOM model [4] to simulate the circulation in order to analyze the upwelling processes in the studied area, the modeled results are illustrated in fig. 5a. The study 
Some circulation features during south-west...

results show that during SW monsoon the northern part of studied area (from Nha Trang to Vung Tau) is in upwelling region with the center being Ninh Thuan's waters. This result is according to satellite data (fig. 5b).
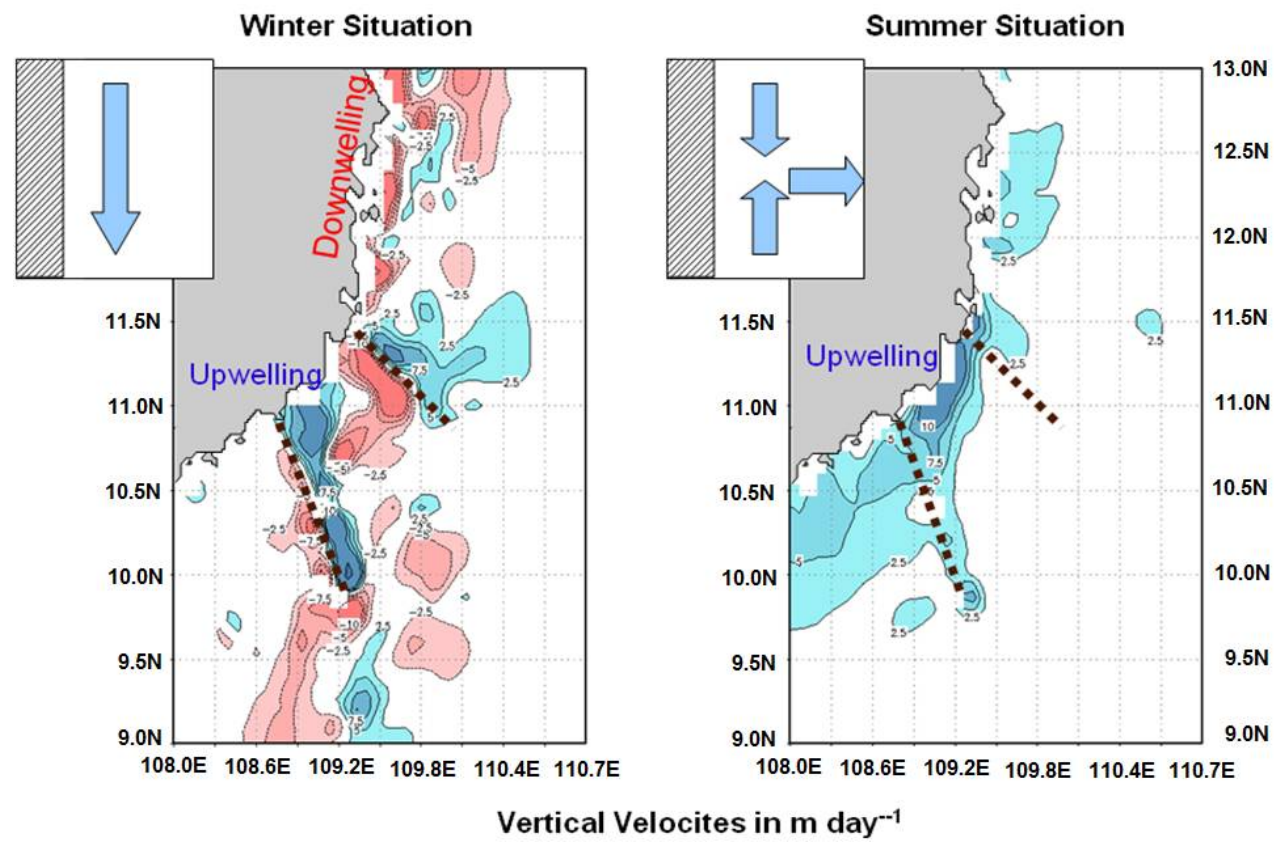

(a) Winter season

(b) Summer season

Fig. 5a. Computed vertical velocity during NE and SW monsoons (Blue color indicates upwelling; Red color indicates down welling)

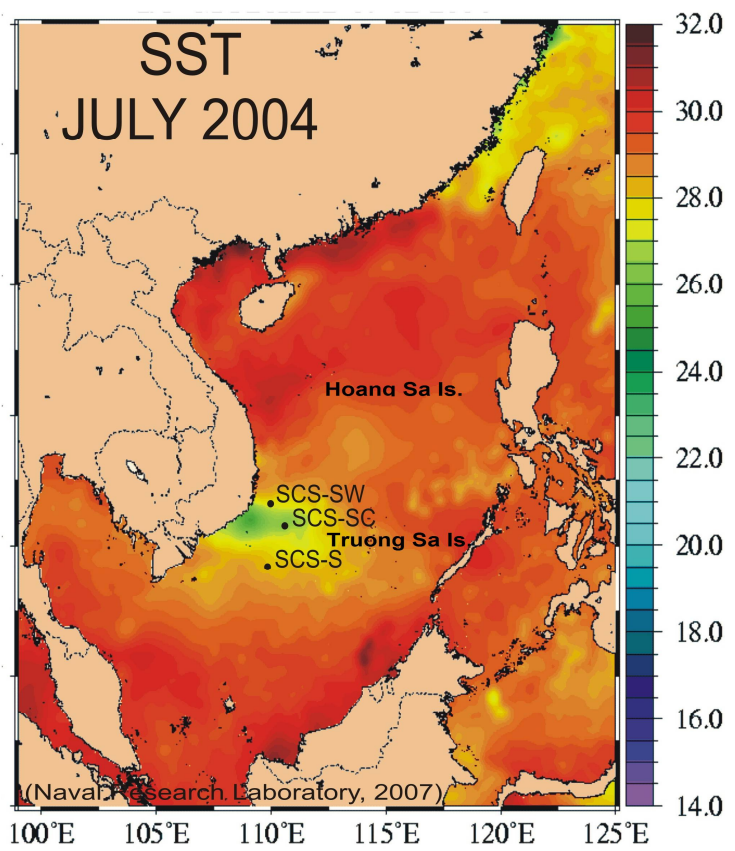

Fig. 5b. Satellite image showing the upwelling phenomenon in South Vietnam waters [8] 
Circulation features in Southern Vietnam's waters

Base on measured data from different projects carried out in the recent years, we have the current pattern for SW monsoon period (fig. 6). It indicates that during SW monsoon the current flows from the south to the north. That means the Mekong river waters can spread to upwelling area.
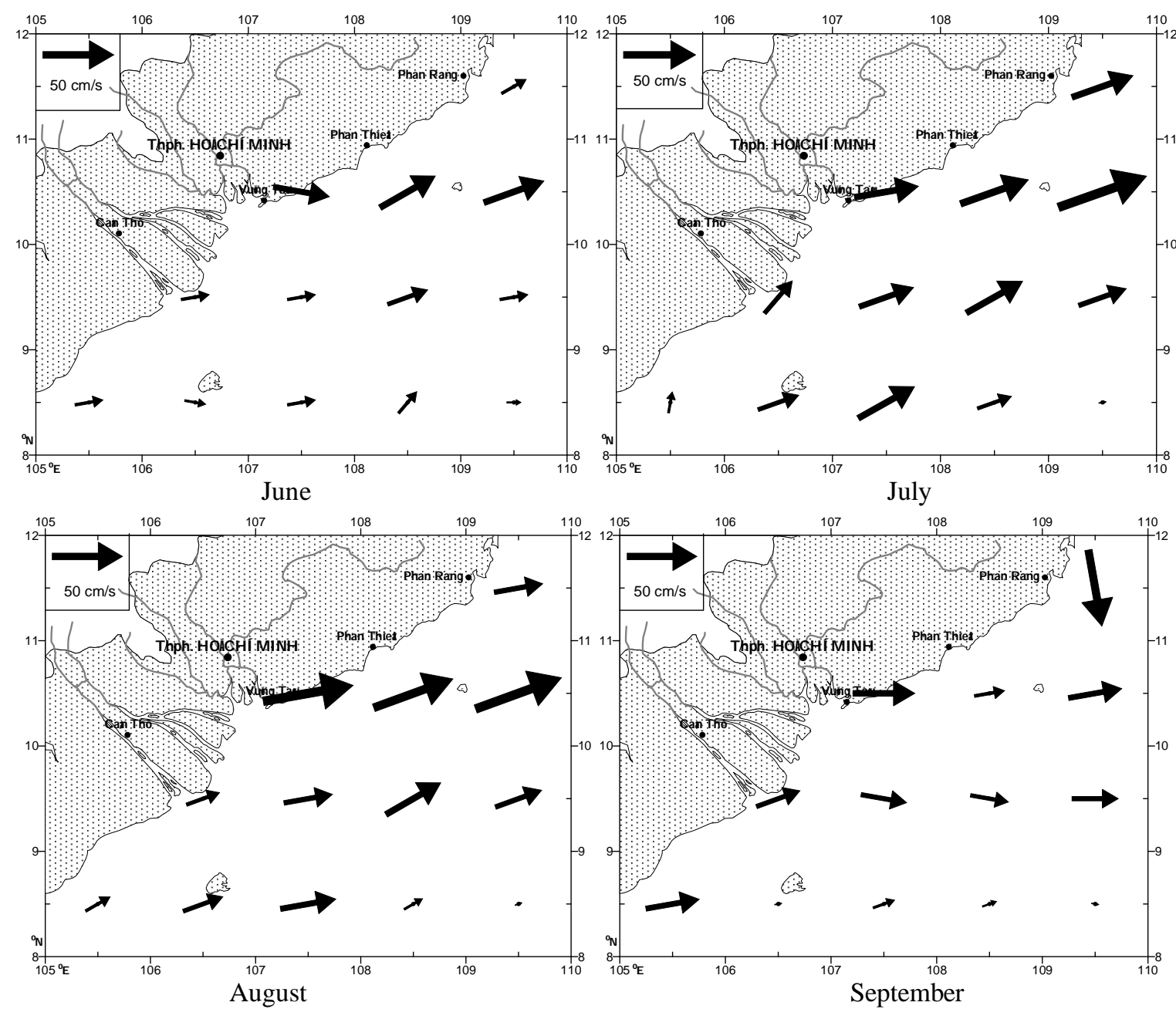

Fig. 6. Surface current pattern in SW monsoon

\section{Spreading of Mekong river waters}

Mekong river mouth and upwelling areas are the most important regions for economic development and environmental protection of Vietnam. This section presents the dispersion of Mekong river waters to the Eastern Vietnam Sea, especially to the upwelling area. Study results show that during $\mathrm{SW}$ monsoon season and high river discharge, the waters from Mekong river mouth region spread into the upwelling area. In September 2009, the Mekong river waters with $S \leq 32$ psu spread up to $80-100 \mathrm{~km}$ offshore with the thickness of about $15 \mathrm{~m}$ (fig. 7a) and spread northwards to $\mathrm{La}$ Gi region (fig. $7 \mathrm{~b}$ ) with the thickness of about 10 m. During August 2009 an intrusion of Mekong river waters was observed on the Vung Tau transect with the thickness from the surface to the bottom (fig. 7c). Data from satellite images (fig. 7d) agreed with measured ones. 
Some circulation features during south-west...

\section{Comments:}

The features of upwelling and Mekong river water spreading into the Eastern Vietnam Sea depend on the conditions of the western boundary current in the Eastern Vietnam Sea and on the Mekong river discharge.

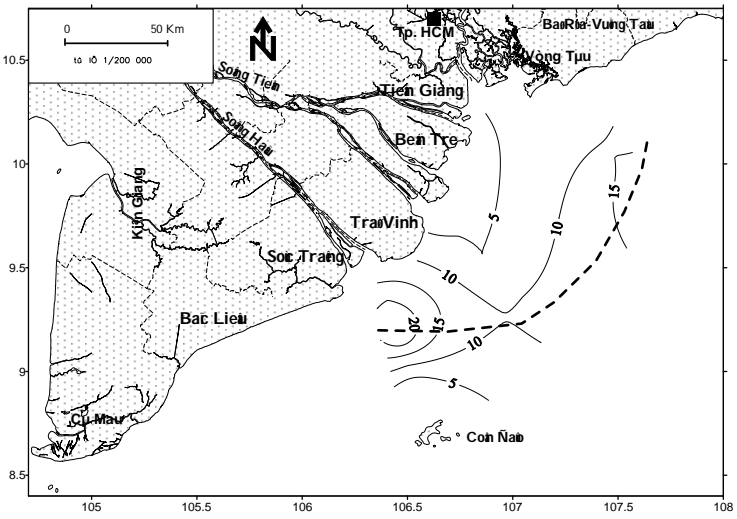

Fig. 7a. Distribution of the thickness (m) of Mekong river waters in September 2009 $(\mathrm{S} \leq 32 \mathrm{psu})$

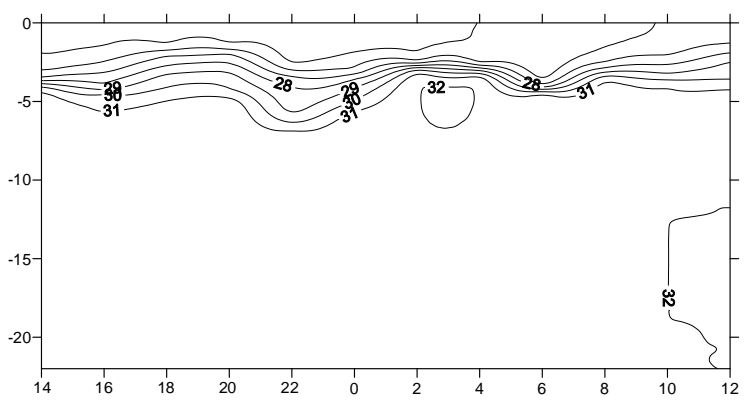

Fig. 7b. Distribution of salinity (psu) at anchored station (Vung Tau transect) during $14 \mathrm{~h} / 19 / 8$ - $12 \mathrm{~h} / 20 / 8 / 2009$ (Horizontal axis: times-h; vertical axis: water depth-m)

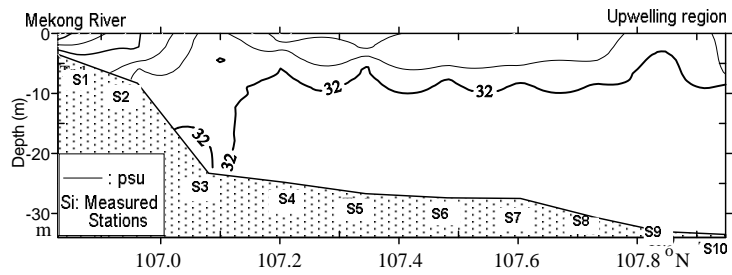

Fig. 7c. Distribution of salinity (psu) along the transect Dai Mouth - La Gi (8/2009)

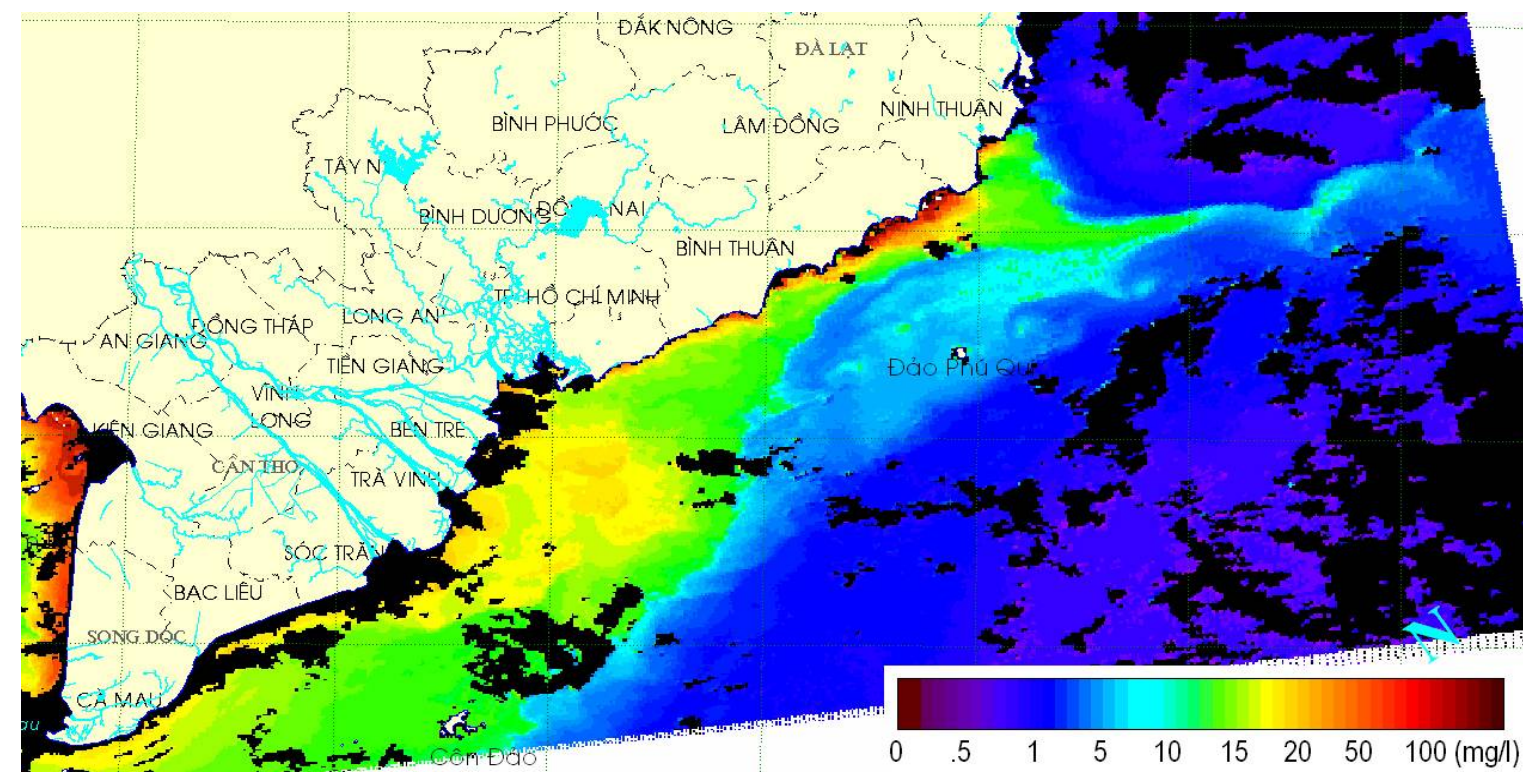

Fig. $7 d$. SPM concentration on 24/9/2009 (MODIS Image)

During the SW monsoon and high river discharge, Mekong river waters spread up to about $80 \mathrm{~km}$ to $100 \mathrm{~km}$ offshore, inclining to the northern part of the studied area towards the transect between $\mathrm{Ke}$ Ga headland and Phu Quy island. The extent of Mekong river waters with characteristics of $S \leq 32$ psu in case of high river discharge and prevailing SW monsoonal wind can reach Phan Thiet and enter the Con Dao and Phu Quy island regions. The transect Phan Thiet 
- Phu Quy marks the front of two water masses (upwelling and Mekong river waters) (fig.7d). In case of highest Mekong river discharge $(10 / 2005)$, the river waters can reach as far as $200 \mathrm{~km}$ offshore. The thickness of Mekong river waters ( $\leq 32 \mathrm{psu}$ ) at the transect Long Hai (off Vung Tau) is about $10 \mathrm{~m}$.

\section{CONCLUSIONS}

The main hydrodynamic processes in Southern Vietnam's waters are driven by the monsoonal wind regime. Remarkable features are the region of strongest upwelling occurring in Ninh Thuan - Binh Thuan waters during the SW monsoon.

Measured data during August and September 2009 indicate that Mekong river waters ( $\mathrm{S} \leq 32 \mathrm{psu})$ spread up to about $80 \mathrm{~km}$ to $100 \mathrm{~km}$ offshore, inclining to the northern part towards the transect between $\mathrm{Ke} \mathrm{Ga}$ headland and Phu Quy island (upwelling area).

The extent of river water spreading is directly proportional to the Mekong river discharge and SW monsoon intensity. Spreading of Mekong river waters to the upwelling area is significant data for assessment of the ecological-environmental effects on the upwelling area.

Acknowledgements: The authors gratefully acknowledge all colleagues in the Institute of Oceanography for their kind help and encouragement throughout the preparation of this paper.

\section{REFERENCES}

1. Shaw, P. T., and Chao, S. Y., 1994. Surface circulation in the south China Sea (Eastern Vietnam Sea). Deep Sea Research Part I: Oceanographic Research Papers, 41(1112), 1663-1683.

2. Pohlmann, T. (1987). A three dimensional circulation model of the South China Sea (Eastern Vietnam Sea). Elsevier oceanography series, 45, 245-268.

3. Dinh Van Uu, 2011. Easttern Vietnam Sea modeling system for marine environmental prediction and monitoring. Proceedings of the $5^{\text {th }}$ National Conference on Marine Science and Technology, Hanoi, Oct. 2011, Vol. 2: Marine Hydrometeorology and Dynamics, pp. 43-49.

4. Hein, H., Hein, B., Pohlmann, T., and Long, B. H., 2013. Inter-annual variability of upwelling off the South-Vietnamese coast and its relation to nutrient dynamics. Global and planetary change, 110, 170-182.

5. Hein, H., Hein, B., and Pohlmann, T., 2013. Recent sediment dynamics in the region of Mekong water influence. Global and Planetary Change, 110, 183-194.

6. Le Dinh Mau, Pham Sy Hoan, Vu Tuan Anh, Nguyen Chi Cong, Nguyen Ba Xuan, 2011. Some meteo-hydro-dynamical features in Mekong river mouth area. Journal of Marine Science and Technology, 11(3), 31-44.

7. Robinson, M. K., 1974. The physical oceanography of the Gulf of Thailand, Naga Expedition. NAGA report.

8. https://www7320.nrlssc.navy.mil/ 